\title{
Methylene tetrahydrofolate reductase and angiotensin converting enzyme gene polymorphisms related to overweight/obesity among Saudi subjects from Qassim Region
}

\author{
Ahmad A Settin ${ }^{\mathrm{a}, *}$, Abdullah Algasham $^{\mathrm{b}}$, Moataz Dowaidar ${ }^{\mathrm{a}}$ and Hisham Ismail ${ }^{\mathrm{c}}$ \\ ${ }^{a}$ Molecular Biology Research Center, College of Medicine, Qassim University, Saudi Arabia \\ ${ }^{\mathrm{b}}$ Department of Pharmacology, College of Medicine, Qassim University, Saudi Arabia \\ ${ }^{\mathrm{c}}$ Clinical Pathology Department, College of Medicine, Qassim University, Saudi Arabia
}

\begin{abstract}
Background: This work was planned to check for the association of polymorphisms related to methylenetetrahydrofolate reductase (MTHFR) and angiotensin converting enzyme (ACE) genes with overweight/obesity among Saudi subjects from Qassim region.

Methods: This work included 130 subjects having overweight or obesity and 111 normal controls. Their age mean $\pm \mathrm{SD}$ was $27 \pm 9.8$ and $24 \pm 8.8$ years respectively. Their DNA was analyzed for polymorphisms of MTHFR; 677C/T and $1298 \mathrm{~A} / \mathrm{C}$ and ACE; I/D genes using real-time PCR.

Results: Genotype and allele frequencies of studied polymorphisms in cases of overweight/obesity showed no significant statistical difference compared to that of controls. However, on analysis of body mass index (BMI), cases showed slightly higher but statistically nonsignificant mean $\pm \mathrm{SD}$ values among those carrying the mutant MTHFR $677 \mathrm{~T}$ allele $(\mathrm{CT}+\mathrm{TT}$ vs. CC, $30.7 \pm$ 4.5 vs. $29.9 \pm 4.9$ ), $1298 \mathrm{C}$ allele (AC $+\mathrm{CC}$ vs. AA, $29.9 \pm 4.1$ vs. $29.7 \pm 5.5$ ) and ACE D allele (ID + DD vs. II, $30.0 \pm 5.1$ vs. $29.1 \pm 2.8$ ). In addition controls having the DD and ID genotypes showed higher statistically significant values of BMI than those of the II genotype (22.0 $\pm 1.9,21.7 \pm 2.6$ and $19.5 \pm 2.3$ respectively, $p<0.05)$.

Conclusion: There is no solid association of polymorphisms related to MTHFR and ACE genes with non-complicated overweight or obesity among Saudi subjects from Qassim Region.
\end{abstract}

Keywords: Obesity, Saudi population, MTHFR, ACE, gene polymorphism, Qassim Region

\section{Introduction}

Obesity is an excessive accumulation of body fat and in its gross manifestation poses a real threat to health [1, 2]. It is the most prevalent, chronic medical condition in the developed, as well as in developing countries [3].

\footnotetext{
* Corresponding author: Prof Dr. Ahmad Settin, Prof of Pediatrics and Genetics, Qassim University, BO 6655 Buraydah 51452, Saudi Arabia. Tel.: +96663851317; Mobile: +9665 56040530; Fax: +966 6 3801228; E-mail: settin@mans.edu.eg; settin60@gmail.com.
}

There are a number of etiological factors producing obesity and these include both genetic and environmental factors and hence it is classified as a multifactorial disorder. Endocrine alterations are also an important cause of obesity but are rare, even though obesity influences the functions of the endocrine system [4,5].

Methylenetetrahydrofolate reductase enzyme (MTHFR) plays a central role in folate metabolism by irreversibly catalyzing the conversion of 5,10-methylenetetrahydrofolate to 5-methyltetrahydrofolate, the primary circulating form of folate and a co-substrate for homocysteine (Hcy) methylation to methionine. Its involve- 
ment in the regulation of homocysteine concentration turns it out to be a risk factor for cardiovascular disorders (CVD) [6]. In the MTHFR gene located in chromosome 1 , a common single nucleotide polymorphism is associated with reduced enzyme activity: $\mathrm{C} \rightarrow \mathrm{T}$ in exon 4 at nucleotide 677 , leading to Ala222Val, with the $\mathrm{T}$ allele frequency being around $44 \%$ in Caucasians; and $\mathrm{A} \rightarrow \mathrm{C}$ in exon 7 at nucleotide 1298 , leading to Glu429Ala, with the C allele frequency around $20 \%$ in Caucasians [7,8]. Individuals who are homozygous for the MTHFR 677 less frequent variant (TT) have $30 \%$ of the expected enzyme activity with a reduced folate status and higher serum Hcy levels, while heterozygous carriers have $65 \%$ activity [9]. On the other hand, individuals carrying the $677 \mathrm{CC}$ together with the $1298 \mathrm{CC}$ genotypes have 60 percent activity compared to subjects carrying the 1298AA variant [8].

Epidemiological studies have shown that low folate levels are associated with a high body mass index (BMI) [10]. This finding has potentially important health implications and warrant further investigation particularly for MTHFR gene polymorphisms to determine whether a causal relationship exists and the direction of this relationship [11].

Angiotensin converting enzyme (ACE) catalyzes the formation of angiotensin I to angiotensin II. A polymorphism has been identified in intron 16 in which a 287 base-pair alu sequence was found to be present (insertion or I) or absent (deletion or D) in the population. This enzyme is involved in adipocyte growth and function and the ACE-processed angiotensin II inhibits adipocyte differentiation. Although associations between BMI and ACE polymorphisms have been reported in general populations, the contribution of this gene to severe obesity is generally unknown $[12,13]$.

During the last three decades Saudi Arabia has seen a considerably rising rates for both overweight and obesity [14-18]. Qassim region is a tribal area in the middle zone of Saudi Arabia characteristically having high rate of consanguinity and familial diseases as obesity with diabetes and cardiovascular disorders [19]. This work was planned to check for the association of non-complicated obesity with genetic polymorphisms of MTHFR and ACE genes as potential risk factors for obesity in this population.

\section{Subjects and methods}

This work was designed as a cross sectional case control study. In order to test the direct association of overweight/obesity with MTHFR and ACE genetic polymorphisms, we included healthy subjects after exclusion of all possible endocrinologic or genetic disorders through thorough history taking, examination and relevant investigations. Cases also were selected as being free from all probable complications that might be related to obesity or metabolic disorders like hypertension, diabetes, hyperlipedemias and coronary heart disease. They included 241 unrelated subjects ethnically belonging to Qassim Region taken from those attending Qassim University affiliated Clinics for routine checkups. Of them 130 subjects were affected with simple overweight or obesity with a body mass index $(\mathrm{BMI}) \geqslant$ $25 \%$ including $66(50.8 \%)$ males and $64(49.2 \%)$ females with an age mean \pm SD of 27 (9.8) and a median of 23 years. The others, 111 subjects were taken as a control group having a normal $\mathrm{BMI}<25 \%$ including $57(51.4 \%)$ males and $54(48.6 \%)$ females with an age mean \pm SD of 24 (8.8) and a median of 20 years. An informed consent was obtained from all subjects in addition to an authorized approval that was obtained from the Scientific and Ethical Committees of Qassim University. For all subjects, the BMI or Quetelet's index was conventionally calculated as weight in $\mathrm{kg} /$ (height in meters $)^{2}$. The classifications of BMI were those used by the WHO Expert Committee, 2000: normal $\mathrm{BMI}=18.5-24.99 \mathrm{~kg} / \mathrm{m}^{2}$; overweight BMI = 25.00$29.99 \mathrm{~kg} / \mathrm{m}^{2}$; grade I (obesity) BMI $=30.00-34.99$; grade II (obesity) BMI $=35.00-39.99 \mathrm{~kg} / \mathrm{m}^{2}$; grade III (obesity) BMI $>40 \mathrm{~kg} / \mathrm{m}^{2}$ [20]. Based on that classification, our sample included 76 subjects having overweight, 43 subjects with grade I obesity and 11 subjects with grade II and III obesity.

For all subjects, DNA was extracted from peripheral blood using the MagNA Pure LV blood reagent set (Roche Diagnostics) according to the manufacturer's instruction. Real-time PCR amplifications for C677T, A1298C gene polymorphisms of MTHFR and I/D polymorphism of ACE genes were done using Light Cycler apparatus (Roche Diagnostics). Amplification mix including specific primers and probes (Light Mix, TIB MOLBIOL and Light Cycler Fast Start DNA Master hybridization probes) were purchased from Roche Diagnostics and used in an optimized PCR conditions recommended by the manufacturer.

\section{Statistical analyses}

Data were processed and analyzed using the Statistical Package of Social Science (SPSS, version 10.0). 

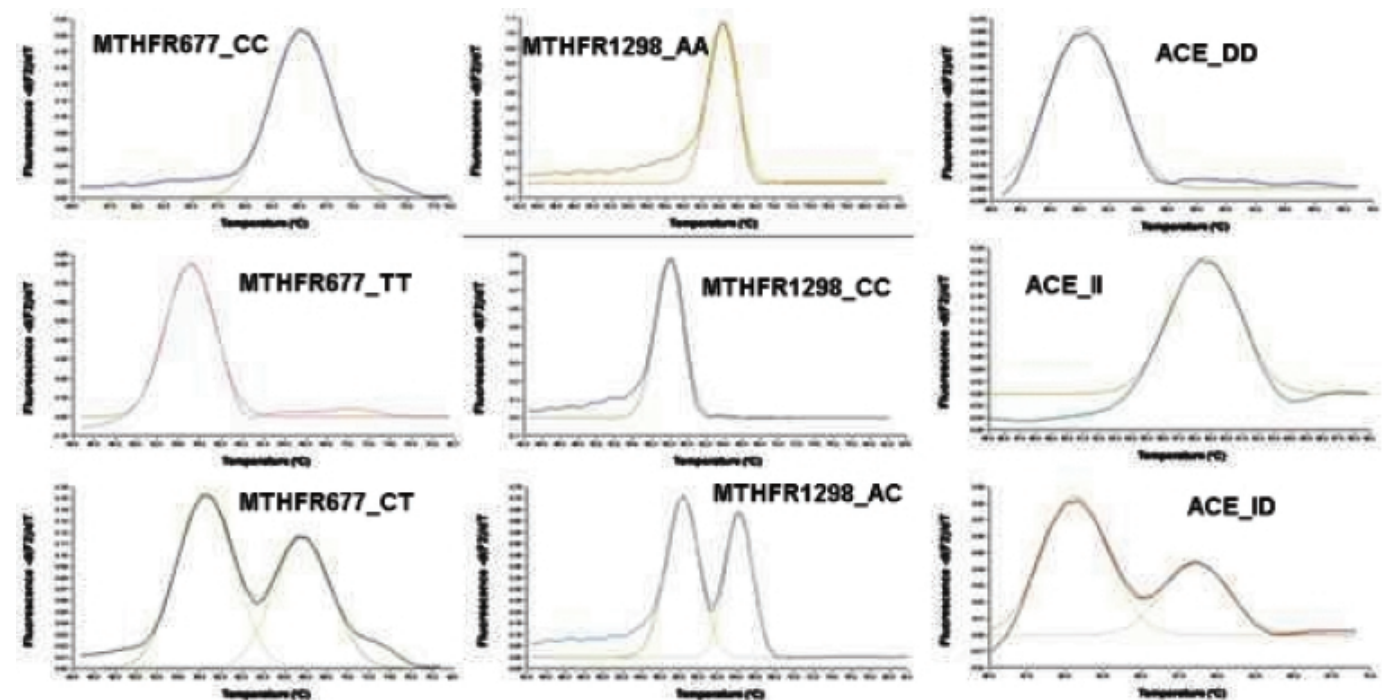

Fig. 1. Real_time PCR tracing showing bands of amplified genes with melting temperatures characteristic for each band.

The frequency of studied allelic polymorphisms among cases was compared to that of controls and tested for positive association using Fisher's exact tests and odds ratio (OR) with $95 \%$ confidence interval $(95 \% \mathrm{CI})$. A minimum level of significance is considered if $\mathrm{P}$ is $\leqslant$ 0.05 . Furthermore, the distribution of alleles in studied groups was tested for fitting to the Hardy-Weinberg equilibrium assuring no significant difference between observed and expected frequencies using $\chi 2$ test.

\section{Results}

Comparing cases having overweight/obesity to controls, no statistical significant difference was observed between both groups in terms of frequencies of all studied MTHFR and ACE genotypes and alleles ( $p>$ 0.05 ) (Table 1). However, on analysis of body mass index (BMI), slightly higher mean values were observed (nonsignificant) among those carrying the MTHFR 677 T allele $(\mathrm{CT}+\mathrm{TT})$ compared to those with CC genotype $(30.7 \pm 4.5$ vs. $29.9 \pm 4.9)$, carriers of the 1298 $\mathrm{C}$ allele (AC + CC) compared to those with AA genotype $(29.9 \pm 4.1$ vs. $29.7 \pm 5.5)$ and among carriers of ACE D allele (ID + DD) compared to those with II genotype $(30.0 \pm 5.1 \%$ vs. $29.1 \pm 2.8 \%)$. In addition controls having the DD and ID genotypes showed statistically significant higher values of BMI than those of the II genotype $(22.0 \pm 1.9,21.7 \pm 2.6$ and $19.5 \pm 2.3$ respectively, $p<0.05$ ) (Table 2 ).

Further analysis comparing controls to higher grade obese subjects (having higher values of BMI) using various combined genotypes and/or haplotypes failed to reveal any significant difference between the two studied group. Analysis of BMI values related to sex in both groups showed non-significant statistical difference except for males in the control group who were ACE D allele carriers who showed significant higher BMI values than females (data not shown).

\section{Discussion}

In this work we attempted testing the association of three genetic polymorphisms pertinent to two important enzymes (MTHFR and ACE) claimed by many authors to have a link to obesity and related complications like hypertension, diabestes, dyslipidemia and cardiovascular disorders [21-25].

In order to assess this association we have selected our cases with simple overweight/obesity without complications and compared them to unrelated matched controls of a same ethnic background. Although no significance could be retrieved comparing the genotype and allele frequencies of studied genes in overweight/obese cases and controls, we could observe a slightly statistically non-significant higher BMI values among subjects carrying the mutant forms of these polymorphisms particularly that of the ACE DD and ID genotypes. This was markedly manifested in male subjects in the control group. This finding is in agreement with the finding of El-Hazmi and Warsy of high frequency of DD genotype and D allele in Saudi over- 
Table 1

Genotypes and allele frequencies of studied genes polymorphisms among overweight/obese cases compared to controls

\begin{tabular}{lcccc}
\hline Genotypes and alleles & Overweight/obes $\mathrm{n}(\%)$ & Control $\mathrm{n}(\%)$ & $\mathrm{P}(\chi 2)$ & OR $(95 \% \mathrm{CI})$ \\
\hline MTHFR 677 & & & & \\
CC & $89(69.5)$ & $69(62.7)$ & 0.33 & $1.4(0.8-2.3)$ \\
TC & $34(26.6)$ & $36(32.7)$ & 0.37 & $0.7(0.43-1.3)$ \\
TT & $5(3.9)$ & $5(4.5)$ & 0.94 & $0.85(0.24-3.03)$ \\
C & $212(82.8)$ & $174(79.1)$ & 0.36 & $1.3(0.81-2.02)$ \\
T & $44(17.2)$ & $46(20.9)$ & 0.36 & $0.79(0.5-1.2)$ \\
MTHFR 1298 & & & \\
AA & $70(54.7)$ & $51(46.4)$ & 0.25 & $1.4(0.84-2.3)$ \\
AC & $45(35.2)$ & $47(42.7)$ & 0.29 & $0.73(0.43-1.23)$ \\
CC & $13(10.2)$ & $12(10.9)$ & 0.98 & $0.92(0.42-2.12)$ \\
A & $185(72.3)$ & $149(67.7)$ & 0.33 & $1.2(0.84-1.84)$ \\
C & $71(27.7)$ & $71(32.3)$ & 0.33 & $0.81(0.54-1.19)$ \\
ACE I/D & & & & \\
II & $12(9.5)$ & $5(4.5)$ & 0.21 & $1.23(0.76-6.55)$ \\
ID & $54(42.9)$ & $44(39.6)$ & 0.71 & $1.14(0.68-1.92)$ \\
DD & $60(47.6)$ & $62(55.9)$ & 0.26 & $0.72(0.43-1.2)$ \\
I & $78(31.0)$ & $54(24.3)$ & 0.13 & $1.4(0.93-2.1)$ \\
D & $174(69.0)$ & $168(75.7)$ & 0.13 & $0.72(0.48-1.08)$ \\
\hline
\end{tabular}

Table 2

Body mass index (mean and SD) related to different polymorphic genotypes among studied overweight/obese cases compared to controls

\begin{tabular}{lcc}
\hline Genotypes & Overweight/obese BMI, $\mathrm{M} \pm \mathrm{SD}$ & Controls BMI, $\mathrm{M} \pm \mathrm{SD}$ \\
\hline MTHFR 677 & & \\
CC & $29.9 \pm 4.9$ & $21.7 \pm 2.5$ \\
CT & $31.1 \pm 4.5$ & $21.8 \pm 1.8$ \\
TT & $28.4 \pm 4.6$ & $23.5 \pm 0.66$ \\
CT + TT & $30.7 \pm 4.5$ & $21.97 \pm 1.8$ \\
MTHFR 1298 & & \\
AA & $29.7 \pm 5.5$ & $21.7 \pm 1.9$ \\
AC & $30.3 \pm 4.1$ & $21.8 \pm 2.5$ \\
CC & $28 \pm 3.9$ & $22.2 \pm 2.6$ \\
AC + CC & $29.9 \pm 4.1$ & $21.8 \pm 2.5$ \\
ACE & & \\
II & $29.1 \pm 2.8$ & $19.5 \pm 2.3$ \\
ID & $30.2 \pm 4.2$ & $21.7 \pm 2.6^{*}$ \\
DD & $29.5 \pm 5.9$ & $22.0 \pm 1.9^{*}$ \\
ID + DD & $30.0 \pm 5.1$ & $21.9 \pm 2.2^{*}$ \\
\hline
\end{tabular}

* Significantly different from the II genotype in the control group $(p<0.05)$

weight and obese individuals in a previous study in Riadh region [26].

Similar finding suggesting that ACE gene polymorphisms may influence the development of weight gain with a sex difference in males and females was previously reported [13,27].

On the other hand, researchers recently reported that there is a trend towards association of ACE I/D polymorphism with hypertension but not with obesity [28]. Likewise, in a rigorous, large-scale Frensh study, authors stated that functionally relevant sequence variation in ACE, whether it is defined at the level of SNPs, haplotypes, or clades, is not associated with obesity [12].
It was reported that MTHFR Ala222Val polymorphism characterized individuals with metabolic obesity with normal weight; and is associated with elevated BMI and waist hip ratio in healthy postmenopausal women [29-31]. Previous researches could also elicit positive association of obesity and hypertension, coronary artery disease or liver diseases with MTHFR C677T mutations [32-34]. Also Thwnashom et al. have reported that folic acid and MTHFR gene polymorphism were found to be significantly related to the overweight/obese and control groups in logistic regression analysis [35].

However, in a recent wide scale study in UK, Lewis et al. denied the initial findings in the British Women's 
Heart and Health Study and concluded a negative association between the MTHFR TT genotype and obesity [11]. Liu et al studying a large sample of Chinese families have also reported no association between the MTHFR gene polymorphism with fat body mass or obesity [36].

From the above mentioned data, it is obvious that these genetic polymorphisms are mostly associated with complicated obesity rather than obesity alone. It may be also related to ethnic background and genetic makeup of each particular population.

Although most of our cases were in the group of overweight rather than the higher grades of obesity, we could presume that there is no solid association of polymorphisms related to MTHFR C677T and A1298C and ACE I/D genes with non-complicated overweight or obesity among Saudi subjects from Qassim Region. However, we recommend a further wider scale and longitudinal study for follow up and genotyping of cases that might develop obesity complications.

\section{References}

[1] H. Shigeta, M. Shigeta, N. Atsuko, N. Nakamura and T. Yoshikawa, Lifestyle, obesity, and insulin resistance, Am Diabetes Assoc 24 (2001), 608-611.

[2] P.S. Powers, Obesity and the regulation of weight, The Williams and Wilkins Co.: London, 1980.

[3] E. Lara-Pantin, Obesity in developing countries, in: Recent Advances in Obesity Research, E. Berry, S.H. Blondheim, H.E. Eliahou et al., V. London: John Libbey \& Co., 1987, pp. 5-8.

[4] G.A. Bray, Obesity, Lippincott Company: Philadelphia, 1992.

[5] B.A. Reeder, Y. Chen, S.M. Macdonald, A. Angel, L. Sweet and Y. Chen, Regional and rural-urban differences in obesity in Canada, Can Med Assoc J 157 (1997), 10-16.

[6] D.S. Wald, M. Law and J.K. Morris, Homocysteine and cardiovascular disease: evidence on causality from a meta-analysis, BMJ 325(7374) (23 Nov 2002), 1202.

[7] L.D. Botto and Q. Yang, 5, 10-Methylenetetrahydrofolate reductase gene variants and congenital anomalies: a HuGE review, Am J Epidemiol 151(9) (1 May 2000), 862-877.

[8] N.M. van der Put, F. Gabreëls, E.M. Stevens, J.A. Smeitink, F.J. Trijbels, T.K. Eskes, L.P. van den Heuvel and H.J. Blom, A second common mutation in the methylenetetrahydrofolate reductase gene: an additional risk factor for neural-tube defects, Am J Hum Genet 62(5) (May 1998), 1044-1051.

[9] R. Rozen, Genetic predisposition to hyperhomocysteinemia: deficiency of methylenetetrahydrofolate reductase (MTHFR), Thromb Haemost, 78(1) (Jul 1997), 523-526.

[10] J.E. Kimmons, H.M. Blanck, B.C. Tohill, J. Zhang and L.K. Khan, Associations between body mass index and the prevalence of low micronutrient levels among US adults, MedGenMed 8(4) (19 Dec 2006), 59.

[11] S.J. Lewis, D.A. Lawlor, B.G. Nordestgaard, A. TybjaergHansen, S. Ebrahim, J. Zacho, A. Ness, S. Leary and G.D. Smith, The methylenetetrahydrofolate reductase C677T genotype and the risk of obesity in three large population-based cohorts, Eur J Endocrinol 159(1) (159 Jul 2008), 35-40. Epub 2008 Apr 21.

[12] C.G. Bell, D. Meyre, E. Petretto, C. Levy-Marchal, S. Hercberg, M.A. Charles, C. Boyle, J. Weill, M. Tauber, C.A. Mein, T.J. Aitman, P. Froguel and A.J. Walley, No contribution of angiotensin-converting enzyme (ACE) gene variants to severe obesity: a model for comprehensive case/control and quantitative cladistic analysis of ACE in human diseases, Eur J Hum Genet, 15(3) (15 Mar 2007), 320-327. Epub 2006 Dec 13.

[13] M.J. Wacker, M.P. Godard, E.H. McCabe, J.E. Donnelly and J.K. Kelly, Sex difference in the association of the angiotensin converting enzyme I/D polymorphism and body mass index, Med Sci Monit 14(7) (14 Jul 2008), CR353-CR357.

[14] G. Baslaim, J. Bashore and K. Alhoroub, Impact of obesity on early outcomes after cardiac surgery: experience in a Saudi Arabian center, Ann Thorac Cardiovasc Surg 14(6) (Dec 2008), 369-375.

[15] N.A. Al-Baghli, A.J. Al-Ghamdi, K.A. Al-Turki, A.G. ElZubaier, M.M. Al-Ameer and F.A. Al-Baghli, Overweight and obesity in the eastern province of Saudi Arabia, Saudi Med J 29(9) (Sep 2008), 1319-1325.

[16] H. Khalid Mel, Is high-altitude environment a risk factor for childhood overweight and obesity in Saudi Arabia? it Wilderness Environ Med 19(3) (2008 Fall), 157-163.

[17] A.A. Alam, Obesity among female school children in North West Riyadh in relation to affluent lifestyle, Saudi Med J 29(8) (Aug 2008), 1139-1144.

[18] T.T. Amin, A.I. Al-Sultan and A. Ali, Overweight and obesity and their relation to dietary habits and socio-demographic characteristics among male primary school children in AlHassa, Kingdom of Saudi Arabia, Eur J Nutr 47(6) (Sep 2008), 310-318. Epub 2008 Aug 1.

[19] M.A. Soyannwo, N.Y. Kurashi, M. Gadallah, J. Hams, O. elEssawi, N.A. Khan, R.G. Singh, A. Alamri and T.H. Beyari, Blood pressure pattern in Saudi population of Gassim, Afr J Med Med Sci 27(1-2) (Mar-Jun 1998), 107-116.

[20] WHO Expert Committee. Obesity: preventing and managing the global epidemic: report of a WHO Consultation on Obesity. WHO Tech Rep Ser 2000; 894.

[21] C.H. Tseng, C.P. Tseng, C.K. Chong, J.J. Sheu and J.C. Cheng, Angiotensin-converting enzyme gene polymorphism and stroke in type 2 diabetic patients in Taiwan, Eur J Clin Invest 37(6) (Jun 2007), 483-491.

[22] A. Muthumala, D.R. Gable, J. Palmen, J.A. Cooper, J.W. Stephens, G.J. Miller and S.E. Humphries, Is the influence of variation in the ACE gene on the prospective risk of Type 2 diabetes in middle-aged men modified by obesity? Clin Sci (Lond) 113(12) (Dec 2007), 467-472.

[23] Y. Hashimoto, A. Futamura, H. Nakarai, H. Yokota, M. Omura, K. Tsukamoto, M. Togo, H. Sato, M. Hara, N. Isoo, J. Taguchi and K. Nakahara, Association between Deletion Polymorphism of Angiotensin Converting Enzyme Gene and Proteinuria in Japanese Overweight Men, J Occup Health 43 (2001), 80-84.

[24] A. Bitigen, C. Cevik, D. Demir, A.C. Tanalp, C. Dundar, K. Tigen, B. Mutlu and Y. Basaran, The frequency of angiotensinconverting enzyme genotype and left ventricular functions in the obese population, Congest Heart Fail 13(6) (Nov-Dec 2007), 323-327.

[25] C. Riera-Fortuny, J.T. Real, F.J. Chaves, M. Morales-SuárezVarela, M.L. Martínez-Triguero, C. Morillas-Ariño and A. Hernández-Mijares, The relation between obesity, abdominal fat deposit and the angiotensin-converting enzyme gene I/D polymorphism and its association with coronary heart disease, 
Int J Obes (Lond) 29(1) (Jan 2005), 78-84.

[26] M.A. El-Hazmi and A.S. Warsy, Increased frequency of angiotensin-converting enzyme DD genotype in Saudi overweight and obese patients, Ann Saudi Med 23(1-2) (Jan-Mar 2003), 24-27.

[27] H. Kramer, X. Wu, D. Kan, A. Luke, X. Zhu, A. Adeyemo, C. McKenzie and R. Cooper, Angiotensin-converting enzyme gene polymorphisms and obesity: an examination of three black populations, Obes Res 13(5) (May 2005), 823-828.

[28] K. Kim, Association of angiotensin-converting enzyme insertion/deletion polymorphism with obesity, cardiovascular risk factors and exercise-mediated changes in Korean women, Eur $J$ Appl Physiol 6 (Jan 2009) [Epub ahead of print].

[29] L. Di Renzo, M. Bigioni, F.G. Bottini, V. Del Gobbo, M.G. Premrov, R. Cianci and A. De Lorenzo, Normal Weight Obese syndrome: role of single nucleotide polymorphism of IL-1 $5 \mathrm{R}$ alpha and MTHFR 677C $\rightarrow \mathrm{T}$ genes in the relationship between body composition and resting metabolic rate, Eur Rev Med Pharmacol Sci 10(5) (Sep-Oct 2006), 235-245.

[30] I. Lambrinoudaki, G. Kaparos, D. Papadimitriou, T.N. Sergentanis, M. Creatsa, A. Alexandrou, E. Logothetis, G. Christodoulakos and E. Kouskouni, Methylenetetrahydrofolate reductase $\mathrm{C} 677 \mathrm{~T}$ polymorphism is associated with central adiposity and increased androgenicity in healthy postmenopausal women, Eur J Endocrinol 159(3) (Sep 2008), 233-241.

[31] I. Terruzzi, P. Senesi, I. Fermo, G. Lattuada and L. Luzi, Are genetic variants of the methyl group metabolism enzymes risk factors predisposing to obesity? J Endocrinol Invest 30(9) (Oct 2007), 747-753.

[32] O. Fridman, R. Porcile, V. Vanasco, M.N. Junco, L. Gariglio, M.A. Potenzoni, I. Bañes and A. Morales, Study on homocysteine levels and methylenetetrahydrofolate reductase gene variant (C677T) in a population of Buenos Aires City, Clin Exp Hypertens 30(7) (Oct 2008), 574-584.

[33] H.S. Koo, H.S. Lee and Y.M. Hong, Methylenetetrahydrofolate reductase TT genotype as a predictor of cardiovascular risk in hypertensive adolescents, Pediatr Cardiol 29(1) (Jan 2008), 136-141. Epub 2007 Oct 5.

[34] M.L. Frelut, N. Emery-Fillon, J.C. Guilland, H.H. Dao and G.P. de Courcy, Alanine amino transferase concentrations are linked to folate intakes and methylenetetrahydrofolate reductase polymorphism in obese adolescent girls, J Pediatr Gastroenterol Nutr 43(2) (Aug 2006), 234-239.

[35] K. Thawnashom, R. Tungtrongchitr, S. Petmitr, P. Pongpaew, B. Phonrat, A. Tungtrongchitr and F.P. Schelp, Methylenetetrahydrofolate reductase (MTHFR) polymorphism (C677T) in relation to homocysteine concentration in overweight and obese Thais, Southeast Asian J Trop Med Public Health 36(2) (Mar 2005), 459-466.

[36] X. Liu, L.J. Zhao, Y.J. Liu, D.H. Xiong, R.R. Recker and H.W. Deng, The MTHFR gene polymorphism is associated with lean body mass but not fat body mass, Hum Genet $\mathbf{1 2 3}(2)$ (Mar 2008), 189-196. Epub 2008 Jan 8. 


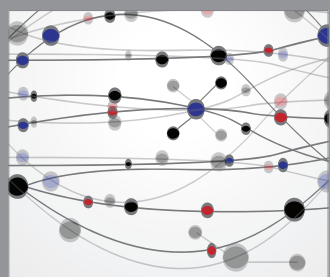

The Scientific World Journal
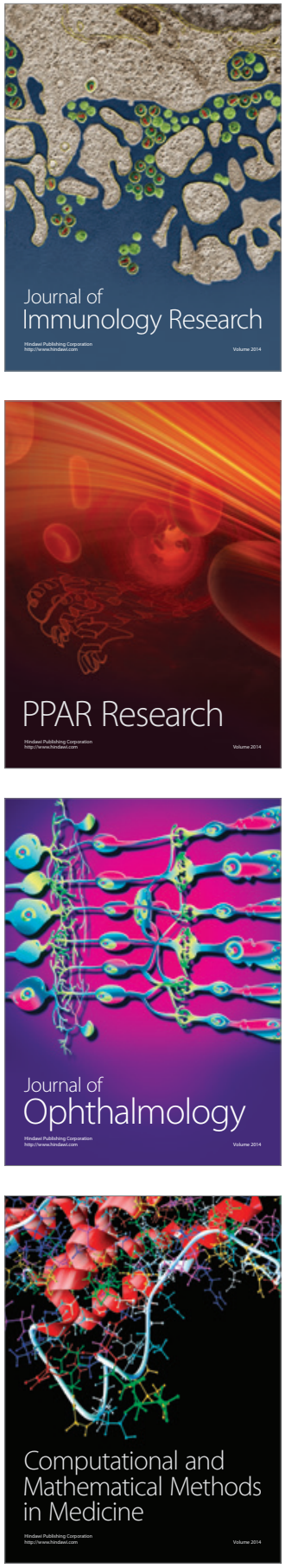

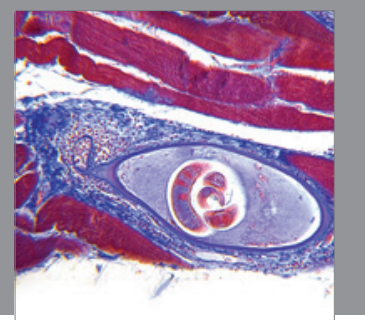

Gastroenterology

Research and Practice
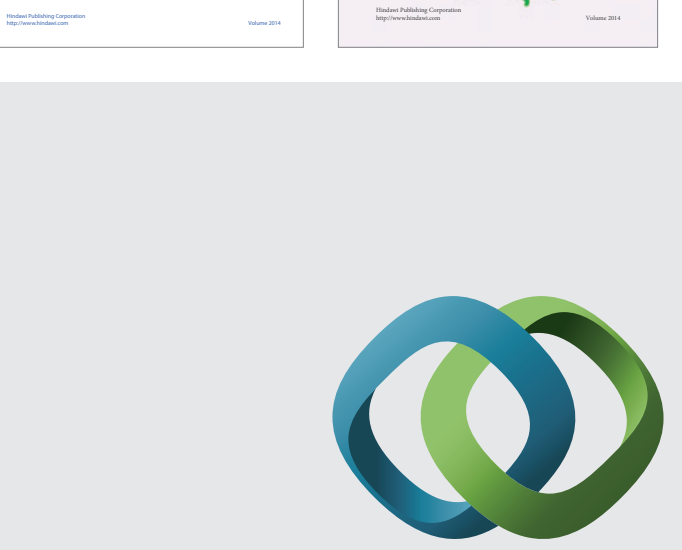

\section{Hindawi}

Submit your manuscripts at

http://www.hindawi.com
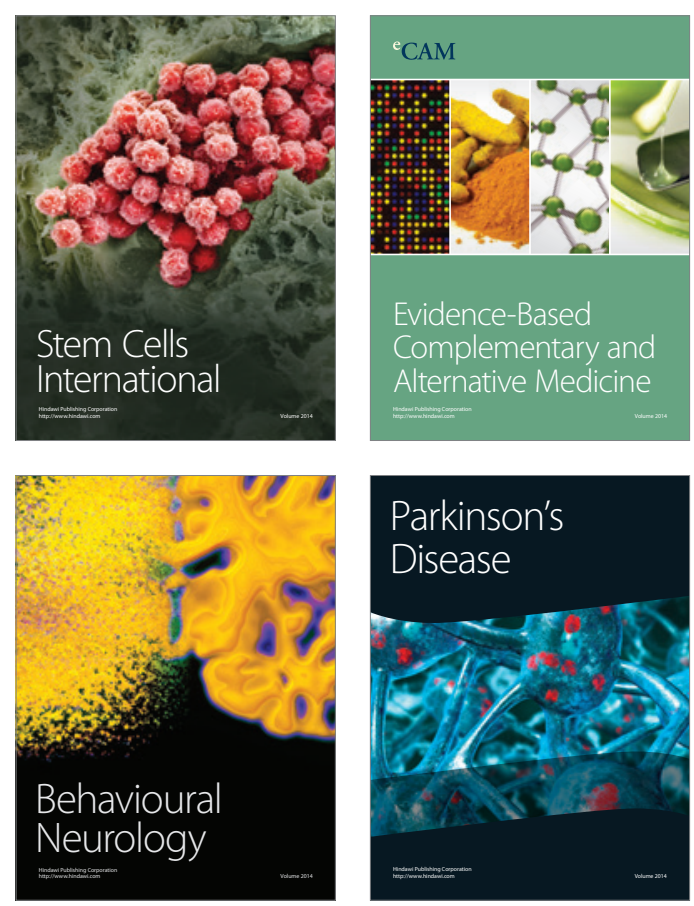

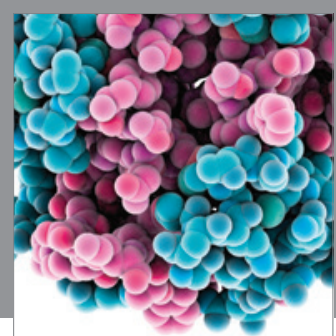

Journal of
Diabetes Research

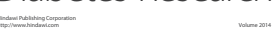

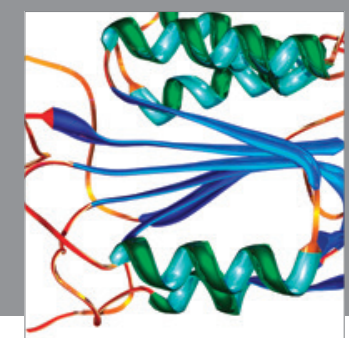

Disease Markers
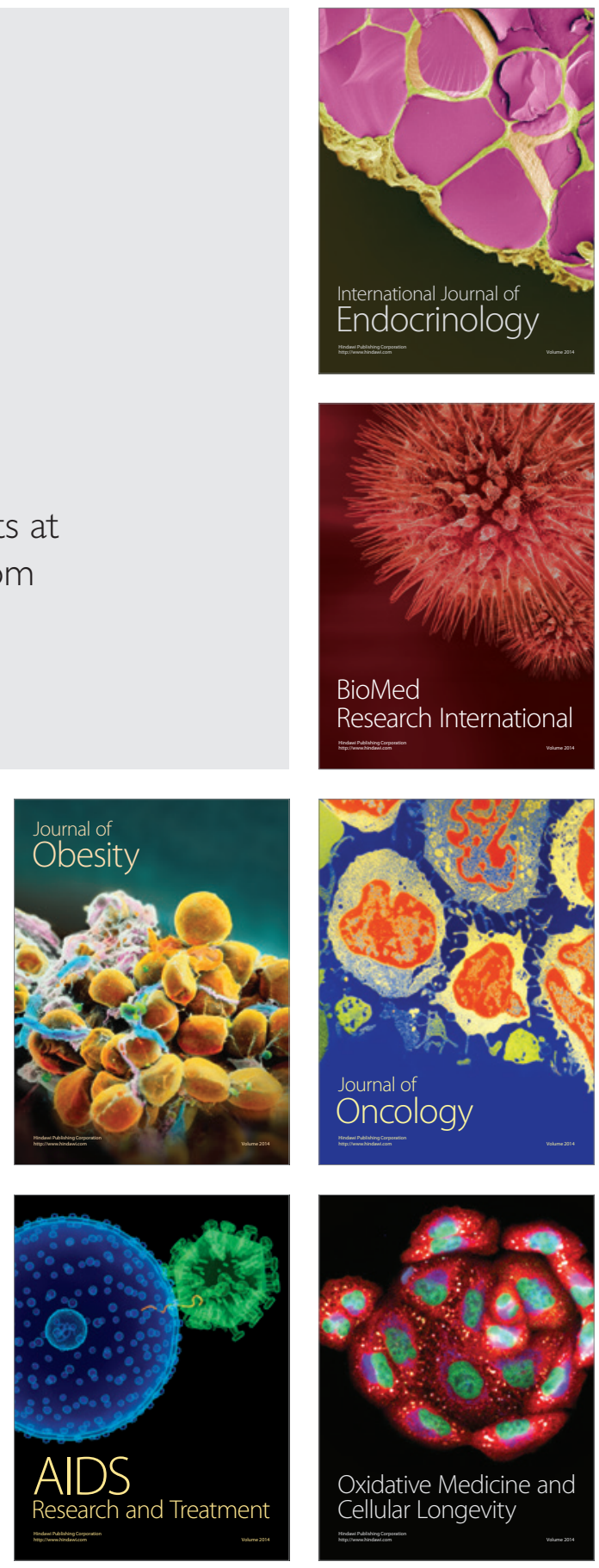